\title{
ANALYSIS OF THE EFFECT OF GROSS REGIONAL DOMESTIC PRODUCT, NUMBER OF POPULATION, REGIONAL MINIMUM WAGE, OPEN UNEMPLOYMENT RATE, AND HUMAN DEVELOPMENT INDEX ON POVERTY IN 2010-2020 EAST JAVA PROVINCE
}

\author{
Nur Ahmar Fajriah*1 \\ ${ }^{1}$ Fakultas Ekonomi dan Bisnis, Universitas Diponegoro, Indonesia
}

\begin{abstract}
Poverty is an economic problem experienced by almost all regions in Indonesia, including East Java Province, where poverty in East Java is relatively high in 2016 East Java Absolute poverty of 4.78 million people. Therefore, it is necessary to find a solution to overcome the problem or reduce poverty. This study aims to analyze the effect of Gross Regional Domestic Product (GRDP), population, Regional Minimum Wage (UMR), open unemployment rate and Human Development Index (IPM) on poverty in East Java Province in 2010-2020. This research uses panel data method with fixed effect model approach, and the data used is secondary data. Adjusted R2 value is quite high. then the results of this study are the variables of GRDP, population, open unemployment rate and HDI have a significant effect on poverty, while the UMR variable has no significant effect on poverty. Therefore, the development of GRDP, population, open unemployment rate should be considered to overcome the problem of poverty.
\end{abstract}

Keywords: Gross Regional Domestic Product, population, Regional Minimum Wage, open unemployment rate, Human Development Index.

\section{ABSTRAK}

Kemiskinan merupakan suatu permasalahan perekonomian yang dialami oleh hampir semua daerah di Indonesia termasuk Provinsi Jawa Timur, dimana kemiskinan di Jawa Timur relatif tinggi pada tahun 2016 kemiskinan Absolut Jawa Timur sebesar 4,78 juta jiwa. Oleh karena itu perlu dicari solusi untuk mengatasi masalah atau mengurangi kemiskinan. Penelitian ini bertujuan untuk menganalisis pengaruh Produk Domestik Regional Bruto (PDRB), jumlah penduduk, Upah Minimum Regional (UMR), tingkat pengangguran terbuka dan Indeks Pembangunan Manusia (IPM) terhadap kemiskinan di Provinsi Jawa Timur tahun 20102020. Penelitian ini menggunakan metode data panel dengan pendekatan fixed effect model, dan data yang digunakan adalah data skunder. Nilai Adjusted $R^{2}$ cukup tinggi. kemudian hasil dari penelitian ini adalah variabel PDRB, jumlah penduduk, tingkat pengangguran terbuka dan IPM berpengaruh signifikan terhadap kemiskinan, sedangkan variabel UMR tidak berpengaruh signifikan terhadap kemiskinan. Oleh karena itu, perkembangan PDRB, jumlah penduduk, tingkat pengangguran terbuka patut menjadi pertimbangan untuk mengatasi masalah kemiskinan.

Kata Kunci: Produk Domestic Regional Bruto, jumlah penduduk, Upah Minimum Regional, tingkat pengngguran terbuka, Indeks Pembangunan Manusia.

JEL: P24, J11, J31, J64, 015

\author{
RIWAYAT ARTIKEL \\ Tanggal Masuk: \\ 25 Juni 2021 \\ Tanggal Revisi: \\ 02 Oktober 2021 \\ Tanggal Diterima: \\ 25 Oktober 2021 \\ Tersedia Online: \\ 29 November 2021 \\ *Korespondensi: \\ Nur Ahmar Fajriah \\ E-mail: \\ nurahmarfajriah@gmail.com
}

JIET (Jurnal IImu Ekonomi Terapan) p-ISSN: 2541-1470; e-ISSN: 2528-1879 




Fajriah N.A. $\quad$ Population, Regional Minimum Wage, Open Unemployment Rate, And Human

Development Index On Poverty In 2010-2020 East Java Province

\section{Pendahuluan}

Kemiskinan merupakan kondisi dimana seseorang atau sekelompok orang tidak mampu untuk mencukupi standar minimum dari kebutuhan layak hidup (KHL), sehingga dalam hal ini kemiskinan dianggap sebagai keadaan kekurangan akan kebutuhan baik berupa uang maupun barang yang digunakan untuk melanjutkan kelangsungan hidupnya. Masalah kemiskinan saat ini sedang menjadi perbincangan disemua negara, kemiskinan juga dianggap sebagai penyakit sosial yang harus ditangani secara serius, oleh karena itu masalah kemiskinan harus dikurangi atau dihilangkan secara bertahap (Yudha, 2013).

Kemiskinan merupakan masalah yang kompleks dan biasanya dipengaruhi oleh beberapa faktor dimana faktor-faktor tersebut saling berkaitan, seperti tingkat pendapatan masyarakat, pengangguran, kesehatan, pendidikan, akses terhadap barang dan jasa, lokasi, keadaaan geografis dan lingkungan. Kemiskinan dapat terjadi apabila masyarakat tidak mampu untuk memenuhi kebutuhan dasar seperti makanan, tempat tinggal dan kesehatan. Selain itu kemiskinan juga dapat terjadi karena kondisi perekonomian yang tidak sama sehingga terdapat masyarakat yang tidak dapat ikut serta dalam proses pembangunan atau menikmati hasil-hasil pembangunan (Soegijoko, 1997).

Selama ini pembangunan ekonomi Indonesia cenderung berpusat di Pulau Jawa, namun pada faktanya masalah kemiskinan banyak terjadi Pulau Jawa terutama pada provinsi D.I Yogyakarta, Jawa Barat, Jawa Tengah dan Jawa Timur.

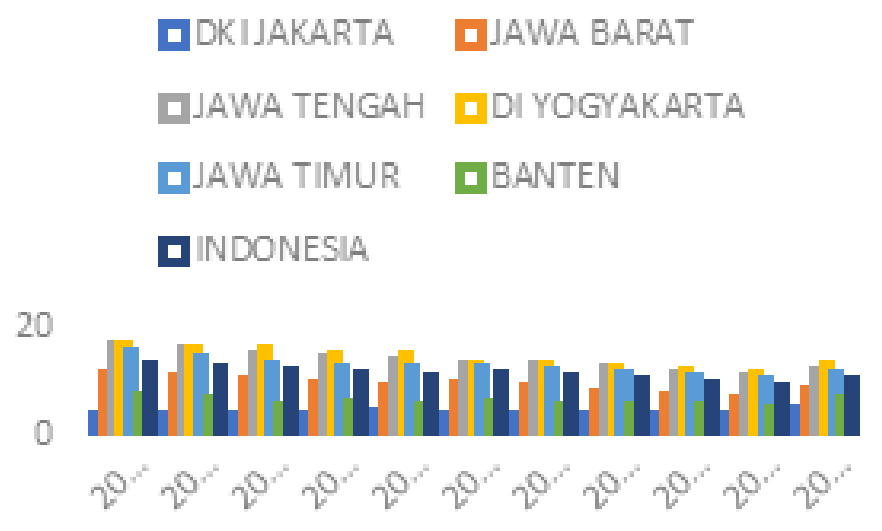

Gambar 1: Tingkat Kemiskinan di Pulau Jawa Dari tahun 2010-2020

Berdasarkan tabel tingkat kemiskinan diatas dapat disimpulkan bahwa tingkat kemiskinan di Pulau Jawa tidak merata dan sebagian besar tingkat kemiskinan diatas $10 \%$ yaitu Provinsi Jawa Barat, Jawa Tengah, Daerah Istimewa Yogyakarta dan Jawa Timur sedangkan untuk Provinsi Banten dan DKI Jakarta dibawah $10 \%$.

Pembangunan adalah suatu proses yang memiliki tujuan untuk kesejahteraan masyarakat dengan cara mengembangkan perekonomian yang ada di masyarakat. Standar dari keberhasilan pembangunan dapat di nilai dari angka pertumbuhan ekonomi. Target dari adanya pembangunan ekonomi selain menciptakan pertumbuhan yang setinggi-tingginya adalah menghilangkan atau menurunkan tingkat kemiskinan. Pertumbuhan ekonomi merupakan salah satu faktor yang sangat penting bagi sebuah negara untuk bisa terlepas dari jerat kemiskinan, dimana pertumbuhan ekonomi bisa dijadikan sebagai acuan oleh sebuah negara bahwa perekonomian dalam negara tersebut mengalami perkembangan dengan tujuan untuk mencapai kesejahteraan. 
Pertumbuhan ekonomi adalah salah satu alat yang dijadikan sebagai tolak ukur untuk melihat kemajuan dan perkembangan suatu bangsa Prasetyo (2009). Petumbuhan ekonomi merupakan indikator yang digunakan untuk melihat keberhasilan sebuah pembangunan dan merupakan salah satu syarat keberhasilan bagi pengurangan tingkat kemiskinan. Adapun syaratnya adalah apabila pertumbuhan ekonomi tersebut dapat dinilai efektif dalam mengurangi kemiskinan. Artinya, dimana pertumbuhan tersebut dapat menyebar pada semua pendapatan, termasuk kedalam golongan penduduk miskin. Secara langsung hal ini berarti bahwa pertumbuhan perlu dipastikan bahwa sudah terjadi di sektor-sektor dimana penduduk miskin bekerja yaitu sektor pertanian atau sektor padat karya. Adapun secara tidak langsung, diperlukan peran pemerintah yang cukup efektif untuk mendistribusikan manfaat pertumbuhan yang mungkin didapatkan dari sketor modern seperti jasa yang padat modal (Siregar \& Wahyuniarti, 2008).

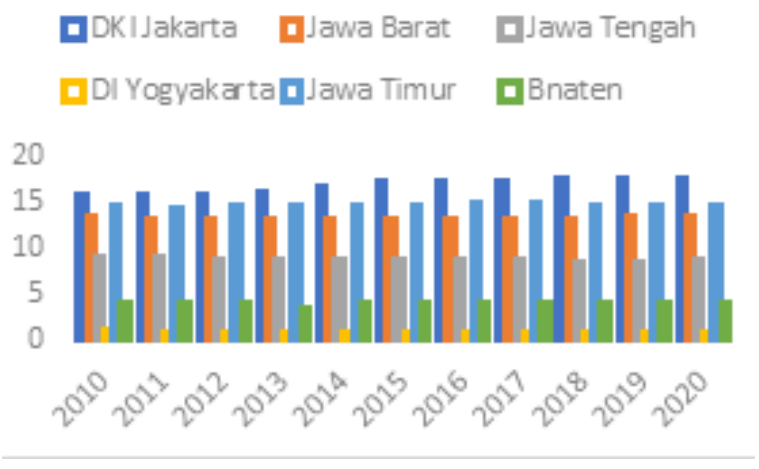

Sumber : Badan Pusat Statistik (2021)

\section{Gambar 2: Pertumbuhan Ekonomi Menurut Harga Berlaku di Pulau Jawa Tahun 2010-2020}

Pertumbuhan ekonomi daerah dapat dilihat dari perubahan Produk Domestic Regional Bruto (PDRB) dalam suatu wilayah. Nilai PDRB akan menunjukan tingkat pembangunan masing-masing daerah tersebut, pada tahun 2010-2015 di Pulau Jawa Provinsi Jawa Timur memiliki nilai PDRB tertinggi kedua setelah DKI Jakarta. Nilai PDRB Provinsi Jawa Timur menunjukan hasil peningkatan setiap tahunnya, akan tetapi nilai PDRB Jawa Timur pada kenyataanya belum mampu untuk mengurangi angka kemiskinan di Provinsi Jawa Timur.

Faktor lain yang dapat menyebabkan kemiskinan adalah pertumbuhan penduduk yang tinggi. Jumlah penduduk yang tidak terkendali akan sangat berpengaruh pada tujuan pembangunan yaitu kesejahteraan masyarakat serta pengurangan angka kemiskinan. Jika angka jumlah penduduk besar maka tingkat kemiskinan akan tinggi atau semakin parah, seperti yang terjadi di negara-negara dengan jumlah penduduk banyak maka cenderung angka kemiskinan tinggi (Saputra, 2011).

Masalah mendasar dalam peningkatan Pendapatan Domestik Regional Bruto (PDRB) dan pembangunan manusia adalah demografi atau faktor kependudukan. Pertumbuhan ekonomi yang dapat dilihat dari peningkatan Produk Domestik Regional Bruto (PDRB) biasanya dipengaruhi oleh pertumbuhan penduduk yang tinggi. Apabila pertumbuhan penduduk tidak terkendali maka akan berakibat pada tidak tercapainya tujuan dari pembangunan ekonomi yaitu kesejahteraan rakyat serta penekanan angka kemiskinan (Saputra, 2011).

Provinsi Jawa Timur merupakan provinsi yang mengalami penambahan jumlah penduduk secara terus menerus, dimana Jawa Timur merupakan provinsi dengan jumlah penduduk terbanyak kedua setelah Jawa Barat (Gambar 3). 


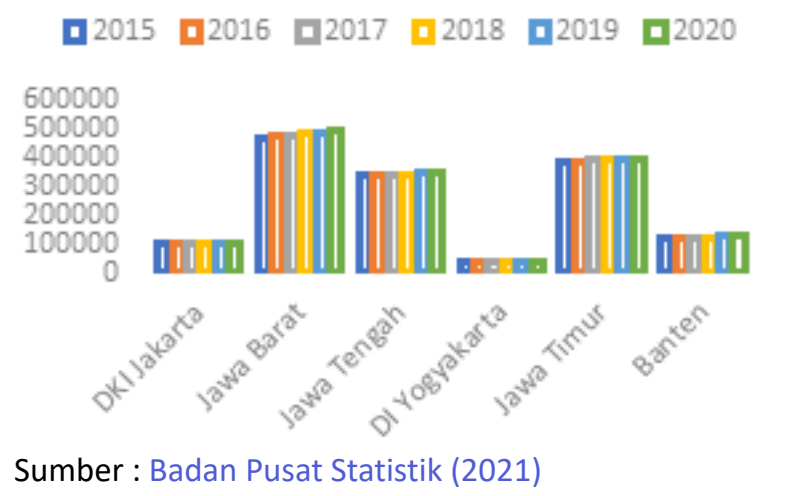

\section{Gambar 3: Jumlah Penduduk Pulau Jawa Tahun 2015 - 2020}

Tingginya angka jumlah penduduk yang tidak di imbangi dengan tersedianya lapangan pekerjaan akan menimbulkan kemiskinan karena akan banyak penduduk usia kerja yang tidak terserap oleh lapangan pekerjaan dalam sebuah daerah. Pada tahun 2019 Provinsi Jawa Timur memiliki jumlah penduduk sebanyak 39,70 juta jiwa, hasil tersebut diperoleh berdasarkan proyeksi penduduk tahun 2010 - 2035, kemudian pada tahun 2020 jumlah penduduk berjumlah 40,67 jiwa yang artinya jumlah penduduk Jawa Timur mengalami peningkatan hampir 1 (satu) juta jiwa dalam kurun waktu satu tahun. Pada tahun 2010 jumlah penduduk Jawa Timur sebanyak 37,56 juta jiwa jadi dalam kurun waktu 11 tahun terakhir jumlah penduduk Jawa Timur bertambah sebanyak 3,11 juta jiwa (Badan Pusat Statistik, 2013).

Selain pertumbuhan ekonomi dan jumlah penduduk upah minimum juga sangat berpengaruh terhadap permasalahan kemiskinan pada suatu negara. Berdasarkan Peraturan Menteri Tenaga Kerja Nomor : Per-01/Men/1999, Upah minimum adalah upah bulanan terendah yang terdiri dari upah pokok termasuk tunjangan tetap. Adapun yang dimaksud tunjangan tetap adalah jumlah upah yang diterima oleh pekerja dengan jumlah yang pasti dimana tidak dipengaruhi oleh kehadiran ataupun capaian prestasi dan lain-lain. Tujuan dari penetapan upah minimum adalah untuk melindungi pekerja atau buruh dari tindakan eksploitasi yang dilakukan oleh pengusaha atau perusahaan dan mendapat upah yang cukup untuk memenuhi kebutuhan hidup minimum (KHM). Jika kebutuhan hidup minimum tercukupi maka masyarakat akan sejahtera dan terbebas dari permasalah kemiskinan (Kristanto, 2014)

Tabel 1: Upah Minimum Regional Provinsi Jawa Timur 2010-2020

\begin{tabular}{cc}
\hline Tahun & UMR \\
\hline 2010 & 630.000 \\
\hline 2011 & 705.000 \\
\hline 2012 & 745.000 \\
\hline 2013 & 866.250 \\
\hline 2014 & 1.000 .000 \\
\hline 2015 & 1.000 .000 \\
\hline 2016 & 1.273 .490 \\
\hline 2017 & 1.388 .000 \\
\hline 2018 & 1.508 .894 \\
\hline 2019 & 1.630 .059 \\
\hline 2020 & 1.748 .777 \\
\hline
\end{tabular}

Sumber : Badan Pusat Statistik (2020) 
Penetapan upah minimum regional menjadi salah satu harapan pemerintah untuk mengentaskan Jawa Timur dari masalah kemiskinan. Peran pekerja/buruh, pengusaha atau pemerintah sangat diperlukan dalam menghadapi dampak dari adanya penetapan upah minimum. Jadi, tidak hanya pengusaha yang menanggung dampak dari adanya penetapan upah minimum ini. Dengan adanya pengertian, pemahaman, dan juga kerjasama dari semua pihak yang tergabung dalam proses industrial ini maka dapat dicapai tujuan dari adanya upah minimum yaitu para pekerja/buruh hidup sejahtera, perusahaan dapat berkembang dengan baik dan pemerintah dapat menjaga dan meningkatkan pertumbuhan ekonomi.

Upah minimum Provinsi Jawa Timur setiap tahunya selalu mengalami peningkatan, dengan adanya peningkatan upah minimum kabupaten/kota diharapkan dapat mendorong dalam meningkatkan kesejahteraan dan produktivitas tenaga kerja. Dalam kurun waktu 11 tahun terakhir kota Surabaya selalu memiliki upah minimum tertinggi dibanding dengan daerah lain hal ini disebabkan karena kota Surabaya merupakan ibu kota Provinsi Jawa Timur.

Jawa Timur merupakan provinsi yang memiliki jumlah penduduk cukup banyak, tercatat pada tahun 2019 jumlah penduduk jawa timur sebanyak 39,74 juta jiwa selaras dengan hal tersebut maka otomatis jumlah angkatan kerja juga tinggi. Per Agustus 2019 jumlah angkatan kerja di Jawa Timur mencapai angka 21,87 juta jiwa dimana jumlah tersebut mengalami peningkatan sebesar 199 ribu jiwa jika dibandingkan dengan agustus 2018. Angkatan kerja itu sendiri memiliki beberapa komponen yaitu penduduk yang bekerja dan juga pengangguran, per Agustus 2019 penduduk Jawa Timur yang bekerja sebanyak 20,66 juta jiwa sedangkan pengangguranya sebesar 0,84 juta orang jika dibandingkan dengan Agustus 2018 jumlah penduduk yang bekerja bertambah 2016 ribu orang dan jumlah pengangguran berkurang 6,72 ribu orang (Badan Pusat Statistik, 2019).

Tingkat Pengangguran Terbuka (TPT) adalah indikator yang dapat digunakan untuk mengukur tingkat penawaran tenaga kerja yang tidak digunakan atau tidak terserap oleh pasar kerja. Tingkat pengangguran Jawa Timur mengalami fluktuasi dari tahun 2014-2019 dan cenderung turun (gambar 4 ).

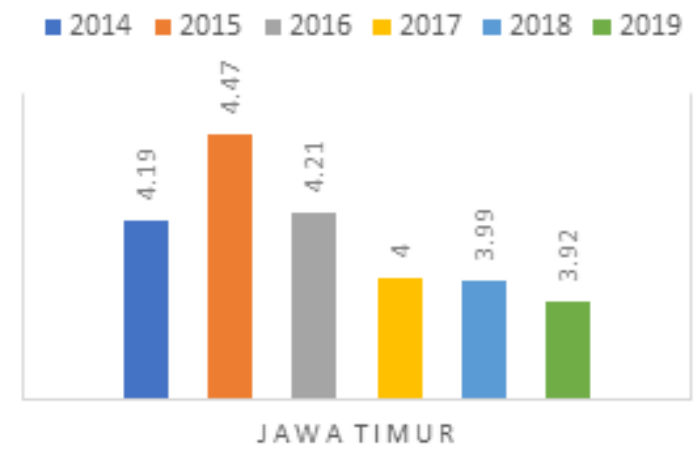

\section{Gambar 4: Tingkat Pengangguran Terbuka Jawa Timur 2014-2019}

Upaya dalam menurunkan tingkat pengangguran dan kemiskinan sangatlah penting. Secara teori jika masyarakat tidak menganggur maka masyarakat tersebut mempunyai sebuah pekerjaan dimana dari pekerjaan tersebut akan diperoleh sebuah pendapatan yang mana pendapatan tersebut dapat digunakan untuk memenuhi kebutuhan layak hidup. Jika kebutuhan hidup tersebuat telah terpenuhi maka masyarakat tersebut tidak tergolong pada masyarakat miskin. Maka dapat disimpulkan bahwa jika tingkat pengangguran rendah makan tingkat kemiskinan juga rendah (Yacoub, 2012). 
Faktor lain yang dapat mempengaruhi kemiskinan adalah kualitas sumber daya manusia, kualitas sumber daya manusia sendiri dapat diukur dari indeks kualitas hidup atau indeks pembangunan manusia (IPM). IPM merupakan indikator penting yang digunakan untuk mengukur keberhasilan dalam mengukur kualitas sumber daya manusia IPM menjelaskan bagaimana penduduk dapat mengakses hasil pembangunan dalam memperoleh pendapatan, kesehatan, pendidikan, dan sebagainya (Saputra, 2011)

IPM merupakan indikator yang digunakan untuk melihat perkembangan pembangunan dalam jangka panjang. Untuk melihat kemajuan pembangunan manusia, terdapat dua aspek yang perlu diperhatikan, yaitu kecepatan dan status pencapaian. Pembangunan manusia di Jawa Timur kontinu mengalami kemajuan selama periode 2012-2018. Dari 66,74 (2012) meningkat menjadi 70,77 (2018) atau selama periode tersebut tumbuh 6,1 persen. Rata-rata pertumbuhan selama kurun waktu 2012-2018 sebesar 0,98 persen per tahun.

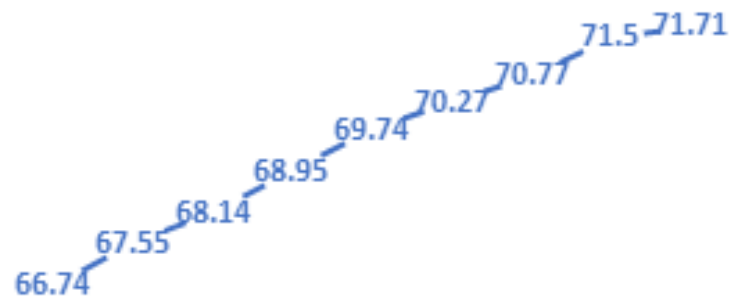

201220132014201520162017201820192020

Sumber : Badan Pusat Statistik (2021)

\section{Gambar 5: Indeks Pembangunan Manusia Jawa Timur 2012 - 2020}

Gambar 1.6 menunjukkan bahwa upaya pemerintah Jawa Timur dalam meningkatkan pembangunan manusia cukup berhasil. Keberhasilan in ditunjukkan oleh pertama kalinya, di seluruh wilayah kabupaten/ kota di Jawa Timur tidak ada yang berkategori "rendah". Walaupun demikian, pemerintah Jawa Timur tetap perlu meningkatkan kinerja pembangunan manusianya, agar tidak terjadi ketimpangan pembangunan manusia antar wilayah di Jawa Timur. Wilayah yang mempunyai IPM tergolong "sedang" diupayakan untuk mencapai kategori "tinggi".

\section{Telaah Literatur}

\section{Kemiskinan}

Menurut Badan Pusat Statistik (2006) pada dasarnya kemiskinan dapat dikelompokkan menjadi dua bagian : a) Kemiskinan absolut adalah kemiskinan yang berkaitan dengan tingkat pendapatan dan kebutuhan yang terbatas pada kebutuhan pokok sehingga orang tersebut dapat disebut hidup dengan layak. Kemiskinan absolut diukur dengan membandingkan tingkat pendapatan seseorang dengan tingkat pendapatan yang diperlukan untuk mendapatkan kebutuhan dasarnya tersebut dengan tujuan kelangsungan hidupnya. Dengan demikian, seseorang dikatakan miskin absolut apabila pendapatan yang diperolehnya kurang dari garis kemiskinan dan tidak mampu mencukupi kebutuhan pokoknya. b) Kemiskinan relatif dilihat dari aspek ketimpangan sosial. Apabila seseorang sudah mampu memenuhi kebutuhan dasar minimumnya, namun masih jauh lebih rendah bila dibandingkan dengan masyarakat di sekitarnya, maka orang tersebut termasuk kategori miskin relatif. Semakin tinggi kesenjangan 
tingkat pendapatan antara golongan atas dengan golongan bawah maka akan semakin tinggi pula jumlah penduduk miskin. Dengan demikian, kemiskinan relatif berhubungan erat dengan distribusi pendapatan.

Sharp (2000) mengidentifikasi penyebab kemiskinan menjadi beberapa bagian antara lain : a) Kemiskinan secara mikro kemiskinan terjadi disebabkan oleh tidak meratanya kepemilikan sumber daya sehingga jumlah pendapatan yang dimiliki oleh masing-masing individu atau rumah tangga mengalami ketimpangan dimana para penduduk miskin hanya memiliki sumber daya yang terbatas dan pendapatanya rendah. b) Perbedaan kualitas sumber daya manusia juga menjadi faktor pemicu terjadinya kemiskinan di masyarakat. Apabila kualitas sumber daya manusia rendah maka akan berpengaruh terhadap produktivitas dalam bekerja dimana akan berakibat pada rendahnya upah yang diperoleh.

\section{Product Domestik Regional Bruto (PDRB)}

Kuncoro (2004) mengatakan bahwa pendekatan pembangunan tradisional lebih dimaknai sebagai pembangunan yang lebih fokus pada peningkatan PDRB suatu provinsi, kabupaten atau kota. Sedangkan pertumbuhan ekonomi dapat dilihat dari pertumbuhan angka Produk Domestik Regional Bruto (PDRB). PDRB baru pada umumnya dihitung berdasarkan dua pendekatan, yaitu pendekatan dari sisi sektoral atau lapangan usaha dan dari sisi penggunaan. Selain itu PDRB juga dihitung berdasarkan harga berlaku dan harga konstan. Total PDRB menunjukan jumlah seluruh nilai tambah yang dihasilkan oleh penduduk dalam periode tertentu.

Produk Domestik Regional Bruto (PDRB) menurut Badan Pusat Statistik (2013) merupakan semua barang dan jasa sebagai hasil dari kegiatan-kegiatan ekonomi yang beroperasi di wilayah domestik, tanpa memperhatikan faktor produksinya berasal dari atau dimiliki oleh penduduk daerah yang bersangkutan. Produk Domestik Regional Bruto (PDRB) atas harga berlaku menggambarkan nilai tambah barang dan jasa yang dihitung menggunakan harga dari setiap tahunnya, PDRB harga berlaku digunakan untuk menunjukan besarnya struktur perekonomian dan peranan sektor yang ada. Sedangkan, Produk Domestik Regional Bruto harga konstan menggambarkan nilai tambah barang dan jasa yang dihitung menggunakan harga pada tahun tertentu sebagai dasar acuan yang ada, PDRB harga konstan digunakan untuk melihat pola pertumbuhan dari tahun ke tahun.

\section{Jumlah Penduduk}

Menurut Badan Pusat Statistik (2005) pertumbuhan penduduk merupakan hasil akumulasi dari perubahan jumlah penduduk pada suatu daerah tertentu dan pada waktu tertentu dari waktu sebelumnya. Kecepatan dari pertumbuhan penduduk akan menimbulkan masalah serius bagi kesejahteraan masyarakat. Jika pertumbuhan penduduk tidak diimbangi dengan dukungan perekonomian yang tinggi maka akan menimbulkan berbagai masalah seperti kemiskinan dan ketidakstabilan kondisi nasional secara keseluruhan.

Menurut Skousen (2009) Malthus mengatakan bahwa populasi penduduk akan terus bertambah menurut deret ukur (secara geometris), sedangkan sumber daya alam akan bertambah menurut deret hitung (secara aritmatika). Akibat dari ketidaksinambungan penambahan antara populasi penduduk dan sumber daya alam adalah bumi tidak mampu memenuhi kebutuhan penduduk yang bersifat tidak terbatas sedangkan sumber daya yang tersedia bersifat terbatas. Jadi, apabila perkembangan sumber daya tidak dapat memenuhi perkembangan penduduk maka akan menjadi penyebab terjadinya kemiskinan. 


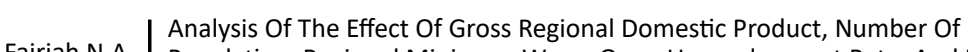

Fajriah N.A. Population, Regional Minimum Wage, Open Unemployment Rate, And Human

Development Index On Poverty In 2010-2020 East Java Province

\section{Upah Minimum}

Upah minimum adalah suatu standar minimum yang digunakan oleh para pengusaha atau pelaku industri untuk memberikan upah kepada pekerja di dalam lingkungan usaha atau kerja. Kebijakan upah minimum di Indonesia tertuang dalam peraturan Menteri Tenaga Kerja Nomor : Per-01/Men/1999 dan UU Ketenagakerjaan No 13 tahun 2003. Upah minimum adalah upah bulanan terendah yang terdiri dari upah pokok termasuk tunjangan tetap. Adapun yang dimaksud tunjangan tetap adalah total imbalan yang didapatkan oleh tenaga kerja yang secara tetap dan teratur pembayarannya, dimana di ikatkan pada kehadiran atupun pencapaian prestasi tertentu.

Menurut Rachman (dalam Kristanto 2014), tujuan penetapan upah minimum dapat dibedakan secara mikro dan makro. Secara mikro tujuan upah minimum adalah :

a. Sebagai jaring pengaman agar upah tidak merosot

b. Mengurangi kesenjangan antara upah terendah dan tertinggi di perusahaan

c. Meningkatkan penghasilan pekerja pada tingkat paling bawah.

Sedangkan secara makro, penetapan upah minimum bertujuan untuk :

a. Pemerataan pendapatan.

b. Peningkatan daya beli pekerja dan perluasan kesempatan kerja.

c. Perubahan struktur biaya industri sektoral.

d. Peningkatan produktivitas kerja nasional dan peningkatan etos dan disiplin kerja.

e. Memperlancar komunikasi pekerja dan pengusaha dalam rangka hubungan bipartite.

\section{Pengangguran}

Pengangguran adalah sesorang yang tidak memiliki pekerjaan dan sedang dalam proses mencari pekerjaan atau sedang bersiap untuk mencari pekerjaan, merasa tidak mampu bekerja atau yang sedang menunggu pekerjaan (Badan Pusat Statistik, 2010).

Menurut Sukirno (1999) pengangguran adalah sesorang yang tergolong dalam angkatan kerja yang secara aktif sedang dalam mencari pekerjaan pada suatu tingkat upah tertentu, tetapi tidak dapat memperoleh pekerjaan yang diinginkan.

\section{Indeks Pembangunan Manusia}

Indikator pembangunan manusia merupakan salah satu alat ukur yang dapat digunakan untuk menilai kualitas pembangunan manusia, baik dari sisi dampaknya terhadap kondisi fisik manusia (kesehatan dan kesejahteraan) maupun yang bersifat non-fisik (intelektualitas). Pembangunan yang berdampak pada kondisi fisik masyarakat tercermin dalam angka harapan hidup serta kemampuan daya beli, sedangkan dampak non-fisik dilihat dari kualitas pendidikan masyarakat.

Indeks pembangunan manusia merupakan indikator strategis yang banyak digunakan untuk melihat upaya dan kinerja program pembangunan secara menyeluruh di suatu wilayah. Dalam hal ini IPM dianggap sebagai gambaran dari hasil program pembangunan yang telah dilakukan beberapa tahun sebelumnya. Demikian juga kemajuan program pembangunan dalam suatu periode dapat diukur dan ditunjukkan oleh besaran IPM pada awal dan akhir periode tersebut. IPM merupakan ukuran untuk melihat dampak kinerja pembangunan wilayah yang mempunyai dimensi yang sangat luas, karena memperlihatkan kualitas penduduk suatu wilayah dalam hal harapan hidup, intelelektualitas dan standar hidup layak. Pada pelaksanaan 
perencanaan pembangunan, IPM juga berfungsi dalam memberikan tuntunan dalam menentukan prioritas perumusan kebijakan dan penentuan program pembangunan. Hal ini juga merupakan tuntunan dalam mengalokasikan anggaran yang sesuai dengan kebijakan umum yang telah ditentukan oleh pembuat kebijakan dan pengambil keputusan

\section{Metode Penelitian}

\section{Variabel Penelitian}

Dalam penelitian ini menggunakan variabel dependen Kemiskinan, data yang digunakan adalah data tingkat kemiskinan 38 Kabupaten/Kota Provinsi Jawa Timur yang dinyatakan dalam satuan persen pada tahun 2010-2020. Kemudian variabel independen yang digunakan adalah data PDRB yang dinyatakan dalam bentuk presentase pada tahun 2010-2020 di 38 Kabupaten/Kota Provinsi Jawa Timur. untuk variabel independen yang kedua adalah variabel jumlah penduduk yang di nyatakan dalam bentuk jiwa pada tahun 2010-2020 di 38 Kabupaten/Kota di Jawa Timur. variabel yang ketiga adalah Upah Minimum Regional dinyatakan dalam bentuk rupiah tahun 2010-2020 di 38 Kabupaten/Kota di Provinsi Jawa Timur. variabel ke empat adalah data tingkat pengangguran terbuka dimana satuanya adalah persen tahun yang digunakan adalah tahun 2010-2020 di 38 Kabupaten/Kota Provinsi Jawa Timur. variabel yang terakhir adalah Indeks Pembangunan Manusia yang dinyatakan dalam bentuk persen tahun yang digunakan adalah tahun 2010-2020 di 38 Kabupaten/Kota di Provinsi Jawa Timur.

\section{Metode Analisis}

Dalam penelitian ini akan menganalisis pengaruh variabel Produk Dometik Bruto (PDRB), Jumlah Penduduk (JP), Tingkat Pengangguran Terbuka (TPT), Upah Minimum Regional (UMR) dan Indeks Pembangunan Manusia (IPM) terhadap Kemiskinan (KM) yang menggunakan data time series selama 10 tahun yaitu tahun 2010-2020 dan cross section sebanyak 38 kota/kabupaten di Jawa Timur yang menghasilkan 380 observasi. Regresi yang akan digunakan adalah regresi data panel yaitu gabungan antara data time series dan cross section. Dalam penelitian ini penulis akan menggunakan alat pengolahan data dan analisisnya menggunakan program Eviews 10.

Model yang akan digunakan dalam menganalisis faktor-faktor yang mempengaruhi kemiskinakan di Provinsi Jawa Timur ditulis dalam bentuk logaritma dengan tujuan untuk menyamakan bentuk satuanya.

Adapun modelnya adalah sebagai berikut :

$$
\log K M: b_{0}+\log b_{1} P D R B_{i t}+\log b_{2} J p_{i t}+\log B_{3} T P T_{i t}+\log _{4} U M R_{i t}+b_{5} I P M_{i t}+\varepsilon t
$$

Dimana :

$\begin{array}{ll}\text { KM } & =\text { Kemiskinan } \\ P D R B & =\text { Produk Domestik Regional Bruto } \\ J P & =\text { Jumlah Penduduk } \\ T P T & =\text { Tingkat Pengangguran Terbuka } \\ \text { UMR } & =\text { Upah Minimum Regional } \\ I P M & =\text { Indeks Pembangunan Manusia } \\ b_{0} & =\text { Konstanta } \\ i & =\text { Unit Cross Section } \\ t & =\text { Unit Time Series } \\ B & =\text { Koefisien } \\ \varepsilon t & =\text { Faktor-faktor lain / Residual }\end{array}$




\section{Hasil Dan Pembahasan}

\section{Hasil Penyimpangan Uji Asumsi Klasik}

Uji Normalitas

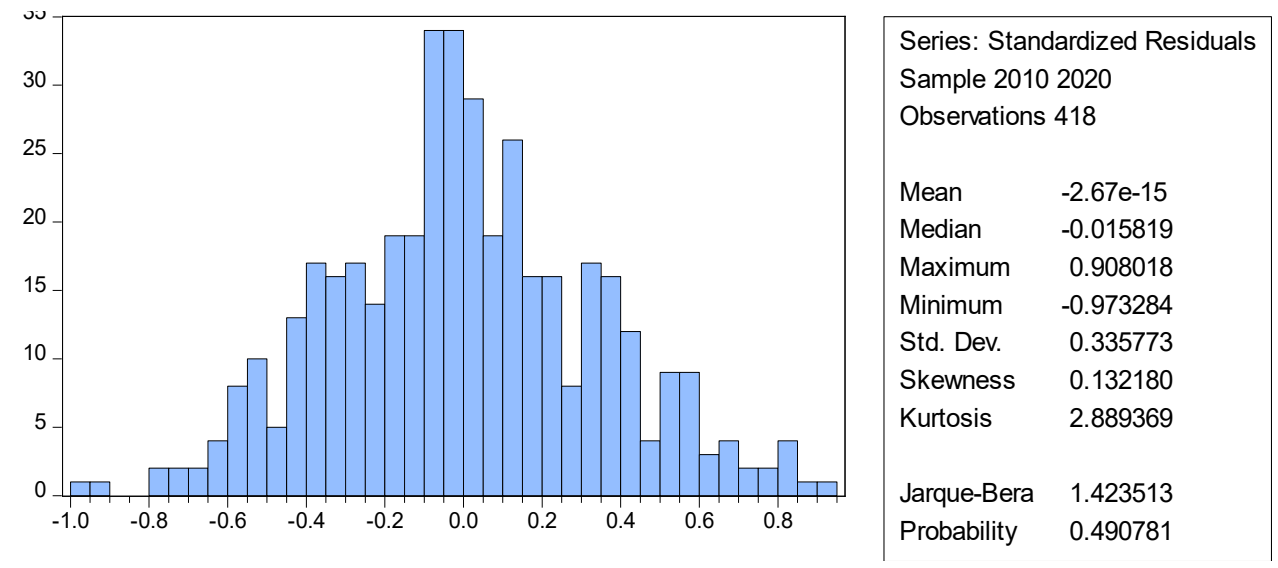

\section{Gambar 6: Hasil Uji Jarque-Bera}

Pada model ini untuk mengetahui data terdistribusi normal atau tidak, maka harus membandingkan antara nilai probabilitas JB hitung harus lebih besar jika dibandingkan dengan tingkat alpha 5\%. Apabila probabilitas JB lebih besar dar 0,05 maka dapat disimpulkan bahwa residual terdistribusi normal atau sebaliknya. Berdasarkan tabel uji normalitas diatas diketahui bahwa nilai probabilitas JB 0.490781 lebih besar dari 0.05, artinya data tersebut terdistribusi normal.

Uji Multikolenioritas

Tabel 2: Uji Multikolenioritas

\begin{tabular}{llllll}
\hline & LogPDRB & LogGJP & LogUMR & LogTPT & IPM \\
\hline LogPDRB & 1.000000 & 0.009509 & 0.365037 & 0.305937 & -0.249693 \\
\hline LogGJP & 0.009509 & 1.000000 & 0.121411 & -0.047248 & -0.049328 \\
\hline LogUMR & 0.365037 & 0.121411 & 1.000000 & 0.177032 & -0.487952 \\
\hline LogTPT & 0.305937 & -0.047248 & 0.177032 & 1.000000 & 0.092353 \\
\hline IPM & -0.249693 & -0.049328 & -0.487952 & 0.092353 & 1.000000 \\
\hline
\end{tabular}

Penilaian uji Multikolenioritas adalah apabila terdapat nilai dibawah 0.8 maka data tersebut terbebas dari masalah Multikolenioritas. Namun apabila terdapat nilai diatas 0.8 maka data tersebut terjangkit masalah Multikolenioritas. Berdasarkan tabel hasil uji Multikolenioritas tidak terdapat variabel yang memiliki nilai lebih besar dari 0.8 sehingga dapat di artikan data tersebut tidak terjangkit masalah Multikolenioritas.

\section{Uji Heteroskedestisitas}

Pengujian Heteroskedestisitas dilakukan dengan cara melihat nilai probabiliti dari masing-masing variabel independent. Apabila terdapat nilai probabiliti yang lebih kecil dari 0.05 maka dalam data tersebut terdapat masalah Heteroskedestisitas, sebaliknya apabila nilai probabiliti dari masing-masing variabel independet lebih besar dari 0.05 maka tidak terdapat masalah Heteroskedestisitas. Berdasarkan tabel diatas semua nilai probabiliti dari masing-masing variabel memiliki nilai lebih dari 0.05 jadi, dapat disimpulkan bahwa data yang digunakan tidak terjangkit masalah Heteroskedestisitas. 
Tabel 3: Uji Heteroskedestisitas (Uji White)

\begin{tabular}{cc}
\hline Variabel & Probabilitas \\
\hline C & 0.9271 \\
\hline LogPDRB & 0.6962 \\
\hline LogGJP & 0.8530 \\
\hline LogUMR & 0.2200 \\
\hline LogTPT & 0.9737 \\
\hline IPM & 0.1939 \\
\hline
\end{tabular}

\section{Uji Autokorelasi}

Dari hasil regresi data panel diatas terdapat 1 variabel dependen dan 5 variabel independen dengan jumlah sampel sebanyak 38 kabupaten/kota di Jawa Timur. Di dapatkan Durbin Watson hitung sebesar 1.859788.

Tabel 4: Uji Autokorelasi

\begin{tabular}{ll}
\hline \multicolumn{2}{c}{ Nilai Durbin-Watson } \\
\hline Durbin-Watson State & 1.85978 \\
\hline
\end{tabular}

Maka nilai $\mathrm{T}=38, \mathrm{k}=6$. Selanjutnya pada tabel durbin watson di dapat $\mathrm{dL}=1.1463$ dan $\mathrm{dU}=1.8641$. pada hasil di atas nilai $\mathrm{d}=1.859788$, maka di hitung terlebih dahulu (4-d) dimana $(4-d)=4-1.859788$ maka hasilnya adalah 2.140212. Jika $2.140212>1.8641$ itu artinya tidak terdapat Autokorelasi negatif

Maka dapat di simpulkan pada analisis regresi panel data di atas tidak terdapat Autokorelasi Positif dan tidak terdapat Autokorelasi Negatif sehingga dapat disimpulkan bahwa tidak terdapat gejala Autokorelasi pada penelitian Analisis pengaruh PDRB, jumlah penduduk, upah minimum regional, tingkat pengangguran terbuka dan indeks pembangunan manusia terhadap kemiskinan di Provinsi Jawa Timur tahun 2010 - 2020.

\section{Pembahasan}

Tabel 5: Uji Statistik F

\begin{tabular}{lr}
\hline F-statistik & 1955.891 \\
\hline Prob (F-statistik) & 0.0000 \\
\hline
\end{tabular}

Dari hasil pengolahan data dengan melakukan uji simultan atau (uji F) maka secara simultan variabel pertumbuhan ekonomi, Jumlah penduduk, upah minimum regional, tingkat pengangguran terbuka dan indeks pembangunan manusia terhadap variabel Kemiskinan. Untuk menentukan nilai Ftabel, maka digunakan tingkat signifikan 5\%. Hasil perhitungan uji $F$ yang diperoleh bahwa variabel independen secara bersama-sama mampu menjelaskan variabel dependen di Provinsi Jawa Timur. Hal ini dijelaskan dengan nilai F-statistic dimana F sebesar 1955.891 dengan $p$ value sebesar 0.00000 yang berarti $<0.05$ atau batas kritis penelitian., sehungga dapat disimpulkan bahwa $\mathrm{H}_{0}$ ditolak.

Jadi kesimpulan dari penelitian ini adalah variabel independen secara simultan atau serempak berpengaruh signifikan terhadap dependen di Provinsi Jawa Timur. 


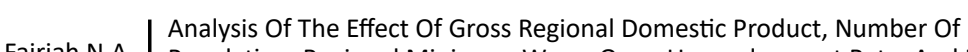

Fajriah N.A. Population, Regional Minimum Wage, Open Unemployment Rate, And Human

Development Index On Poverty In 2010-2020 East Java Province

Tabel 6: Uji Signifikansi Parameter Individual (Uji t)

\begin{tabular}{cccc}
\hline Variabel & Koefisien & t-statistik & Probabilitas \\
\hline C & 25.17034 & 9.325239 & 0.0000 \\
\hline LogPDRB & -0.044251 & -5.149053 & 0.0000 \\
\hline LogGJP & -1.481561 & -7.412385 & 0.0000 \\
\hline LogUMR & -0.011203 & -1.472356 & 0.1418 \\
\hline LogTPT & 0.036784 & 2.556587 & 0.0110 \\
\hline IPM & -5.710006 & -3.417697 & 0.0007 \\
\hline
\end{tabular}

Pengaruh Produk Domestik Regional Bruto terhadap kemiskinan di Provinsi Jawa Timur

Jumlah observasi dalam penelitian ini adalah 418 kemudian jumlah variabel dalam penelitian ini sebanyak 6 (variabel dependen dan independen) dengan alpha 5\%. Hasil pengujian dari regresi data panel diatas menunjukan bahwa hasil t hitung variabel pertumbuhan ekonomi sebesar $-5.149053>2.24962$ lebih besar dari t tabel, dengan nilai probabilitas $0.0000<0.05$ sehingga dapat diartikan bahwa variabel pertumbuhan ekonomi memiliki pengaruh signifikan terhadap kemiskinan di Provinsi Jawa Timur.

Selanjutnya, koefisien beta dalam hasil analisis Eviews dapat dilihat pada tabel coefficient. Koefisien beta merupakan sebuah nilai prediksi dalam suatu variabel bebas dalam model terhadap variabel terikat. Nilai coefficient beta untuk variabel pertumbuhan ekonomi adalah sebesar -0.044251 . Artinya, pertumbuhan ekonomi dapat menjelaskan kemiskinan sebesar - 0.044251 atau dapat dijelaskan apabila terjadi kenaikan satu persen pertumbuhan ekonomi maka dapat mengakibatkan penurunan kemiskinan sebesar 0.04 jiwa. Dalam hal ini faktor lain dianggap konstan. Nilai coefficient sebesar $(-0.044251)$ berarti bahwa tanda negatif (-) menunjukan bahwa variabel pertumbuhan ekonomi memiliki hubungan yang negatif terhadap kemiskinan di Jawa Timur.

\section{Pengaruh Jumlah Penduduk terhadap Kemiskinan di Provinsi Jawa Timur}

Hasil pengujian dari regresi data panel diatas menunjukan bahwa hasil t hitung variabel jumlah penduduk sbesar -7.412385 > 2.24962 lebih besar dari t tabel, dengan nilai probabilitas $0.0000<0.05$ sehingga dapat diartikan bahwa variabel jumlah penduduk memiliki pengaruh signifikan terhadap kemiskinan di Provinsi Jawa Timur.

Selanjutnya, koefisien beta dalam hasil analisis Eviews dapat dilihat pada tabel coefficient. Koefisien beta merupakan sebuah nilai prediksi dalam suatu variabel bebas dalam model terhadap variabel terikat. Nilai coefficient beta untuk variabel jumlah penduduk adalah sebesar -1.481561. Artinya, jumlah penduduk dapat menjelaskan kemiskinan sebesar -1.481561 atau dapat dijelaskan apabila terjadi kenaikan satu jiwa jumlah penduduk maka dapat mengakibatkan penurunan kemiskinan sebesar -1.48 jiwa. Dalam hal ini faktor lain dianggap konstan. Nilai coefficient sebesar (-1.481561) berarti bahwa tanda negatif (-) menunjukan bahwa variabel jumlah penduduk memiliki hubungan yang negatif terhadap kemiskinan di Provinsi Jawa Timur.

\section{Pengaruh Upah Minimum Regional terhadap Kemiskinan di Jawa Timur}

Hasil pengujian dari regresi data panel diatas menunjukan bahwa hasil t hitung variabel UMR sebesar $-1.1472356<2.24962$ lebih kecil dari t tabel, dengan nilai probabilitas 0.1418 $>0.05$ sehingga dapat diartikan bahwa variabel UMR memiliki pengaruh yang tidak signifikan terhadap kemiskinan di Provinsi Jawa Timur. 
Selanjutnya, koefisien beta dalam hasil analisis Eviews dapat dilihat pada tabel coefficient. Koefisien beta merupakan sebuah nilai prediksi dalam suatu variabel bebas dalam model terhadap variabel terikat. Nilai coefficient beta untuk variabel UMR adalah sebesar -0.011203 . Artinya, UMR dapat menjelaskan kemiskinan sebesar -0.011203 atau dapat dijelaskan apabila terjadi kenaikan satu rupiah UMR maka dapat mengakibatkan penurunan kemiskinan sebesar 0.01 jiwa Dalam hal ini faktor lain dianggap konstan. Nilai coefficient sebesar $(-0.011203)$ berarti bahwa tanda negatif (-) menunjukan bahwa variabel UMR memiliki hubungan yang negatif terhadap kemiskinan di Provinsi Jawa Timur.

\section{Pengaruh Tingkat Penganggura Terbuka terhadap Kemiskinan di Provinsi Jawa Timur}

Hasil pengujian dari regresi data panel diatas menunjukan bahwa hasil t hitung variabel TPT sebesar $2.556587>2.24962$ lebih besar dari t tabel, dengan nilai probabilitas $0.0110<$ 0.05 sehingga dapat diartikan bahwa variabel TPT memiliki pengaruh yang signifikan terhadap kemiskinan di Provinsi Jawa Timur.

Selanjutnya, koefisien beta dalam hasil analisis Eviews dapat dilihat pada tabel coefficient. Koefisien beta merupakan sebuah nilai prediksi dalam suatu variabel bebas dalam model terhadap variabel terikat. Nilai coefficient beta untuk variabel TPT adalah sebesar 0.036784 . Artinya, TPT dapat menjelaskan kemiskinan sebesar 0.036784 atau dapat dijelaskan apabila terjadi kenaikan satu persen TPT maka dapat mengakibatkan kenaikan kemiskinan sebesar 0.03 jiwa. Dalam hal ini faktor lain dianggap konstan. Nilai coefficient sebesar $(0.036784)$ berarti bahwa tanda positif (+) menunjukan bahwa variabel TPT memiliki hubungan yang positif terhadap kemiskinan di Provinsi Jawa Timur.

\section{Pengaruh Indeks Pembangunan Manusia terhadap Kemiskinan di Provinsi Jawa Timur}

Hasil pengujian dari regresi data panel diatas menunjukan bahwa hasil t hitung variabel IPM sbesar -3.41767 > 2.24962 lebih besar dari t tabel, dengan nilai probabilitas 0.0007 $<0.05$ sehingga dapat diartikan bahwa variabel IPM memiliki pengaruh signifikan terhadap kemiskinan di Provinsi Jawa Timur.

Selanjutnya, koefisien beta dalam hasil analisis Eviews dapat dilihat pada tabel coefficient. Koefisien beta merupakan sebuah nilai prediksi dalam suatu variabel bebas dalam model terhadap variabel terikat. Nilai coefficient beta untuk variabel IPM adalah sebesar -5.710006 . Artinya, IPM dapat menjelaskan kemiskinan sebesar -5.710006 atau dapat dijelaskan apabila terjadi kenaikan satu persen IPM maka dapat mengakibatkan penurunan kemiskinan sebesar 5.71 jwa. Dalam hal ini faktor lain dianggap konstan. Nilai coefficient sebesar (-5.710006) berarti bahwa tanda negatif (-) menunjukan bahwa variabel IPM memiliki hubungan yang negatif terhadap kemiskinan di Provinsi Jawa Timur.

\section{Tabel 7: Koefisien Determinasi $\left(R^{2}\right)$}

\begin{tabular}{ll}
\hline R-squared & 0.995480 \\
\hline Adj R-squared & 0.994971 \\
\hline
\end{tabular}

Pada tabel diatas, angka $R$-squared adalah sebesar 0.995480 sedangkan angka Adjusted $R$-squared adalah sebesar 0.994971 . Nilai $R$-squared berkisar antar 0 sampai 1 . Apabila hasil $R$-square mendekati 0 artinya variabel independen memiliki kekuatan yang sangat lemah dalam menjelaskan variabel dependen, kemudian apabila hasil $R$-squared mendekati 1 artinya variabel independen maka dapat dikatakan kuat dalam menjelaskan variabel dependen. Kedua hasil tersebut yang lebih baik digunakan adalah nilai Adjust $R$-squared, karena Adjust $R$-square merupakan $R$-square yang telah disesuaikan dengan jumlah variabel yang digunakan. 


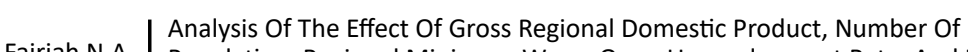

Fajriah N.A. $\quad$ Population, Regional Minimum Wage, Open Unemployment Rate, And Human

Development Index On Poverty In 2010-2020 East Java Province

Dalam penelitian ini nilai Adjust $R$-squared adalah sebesar 0.994971 artinya bahwa variabel terikat yaitu kemiskinann dapat dijelaskan oleh variabel bebas yaitu Produk Domestik Regional Bruto (PDRB), jumlah penduduk, Upah Minimum Regional (UMR), tingkat pengangguran terbuka dan Indeks Pembangunan Manusia (IPM) sebesar 99.49\%. Sedangkan sisanya sebesar $0.51 \%$ lainnya dipengaruhi oleh faktor lain diluar regresi model dalam penelitian ini.

\section{Kesimpulan}

Berdasarkan uraian yang telah dijelaskan pada bab-bab sebelumnya, maka kesimpulan yang dapat diambil adalah sebagai berikut :

(1) Variabel Produk Domestik Regional Bruto (PDRB) berpengaruh signifikan terhadap kemiskinan di Jawa Timur tahun 2010-2020, hal ini dapat disimpulkan bahwa apabila pertumbuhan ekonomi naik maka kemiskinan akan mengalami menurun.

(2) Variabel jumlah penduduk berpengaruh signifikan terhadap kemiskinan di Jawa Timur tahun 2010-2020, hal ini disebabkan oleh tingginya angka penambahan jumlah penduduk dimana tingkat kelahiran tinggi dan tingkat kematian juga tinggi. Namun saat ini sudah jauh lebih baik dan penduduk Jawa Timur saat ini didominasi oleh penduduk usia produktif

(3) Variabel upah minimum berpengaruh tidak signifikan terhadap kemiskinan di Jawa timur tahun 2010-2020. Hal ini disebabkan oleh tingginya tingkat upah yang tidak dibarengi oleh peningkatan hasil usaha perusahaan sehingga perusahaan melakukan PHK yang mana berakibat pada hilangnya pendapatan masyarakat sehingga terjebak dalam lingkaran kemiskinan.

(4) Variabel tingkat pengangguran terbuka signifikan terhadap kemiskinan di Jawa Timur tahun 2010-2020. Adanya pengangguran masyarakat tidak dapat memenuhi kebutuhan hidupnya sehingga masyarakat akan terjerumus kedalam lingkaran kemiskinan.

(5) Variabel indeks pembangunan manusia berpengaruh signifikan terhadap kemiskinan di Jawa Timur tahun 2010-2020. Apabila IPM naik maka produktifitas masyarakat akan mengalami kenaikan dimana produktiftas tersebut dapat berdampak pada peningkatan upah sehingga jumlah pendapatan naik dan masyarakat akan keluar dari lingkaran kemiskinan.

\section{Daftar Pustaka}

Permana, A.Y. \& Arianti, F. (2012). Analisis Pengaruh PDRB, Pengangguran, Pendidikan dan Kesehatan terhadap Kemiskinan di Jawa Tengah Tahun 2004-2009. Diponegoro Journal of Economics, 1.

Aprilia, R. D. (2016). Pengaruh Pertumbuhan Ekonomi, Upah Minimum, Pendidikan dan Tingkat Pengangguran Terhadap Tingkat Kemiskinan di Jawa Timur. jurnal ilmiah Mahasiswa FEB, 4(2).

Ayu, D. S. (2018). Analisis Pengaruh Produk Domestik Bruto, Tingkat Pengangguran Terbuka, Ipm, Jumlah Penduduk dan Upah Minimum Terhadap Kemiskinan di Povinsi Jawa Timur Tahun 2010-2015. Economics.

Badan Pusat Statistik. (2005). Pertumbuhan Penduduk. Badan Pusat Statistik. bps.go.id

Badan Pusat Statistik. (2006). Kelompok Kemiskinan. Jakarta: BPS.

Badan Pusat Statistik. (2013). Produk Domestik Regional Bruto Menurut Lapangan Usaha. Jakarta: Badan Pusat Statistik. 
Badan Pusat Statistik. (2013). proyeksi penduduk indonesia tahun 2010-2035. Jakarta: Badan Pusat Statistik.

Badan Pusat Statistik. (2010). Pengertian Pengangguran. Badan Pusat Statistik. bps.go.id

Badan Pusat Statistik. (2014). Tingkat Kemiskinan di Pulau Jawa. Badan Pusat Statistik. bps. go.id

Badan Pusat Statistik. (2019). Berita Resmi Statistik, Keadaan Ketenagakerjaan Jawa Timur Agustus 2019. Surabaya: Badan Pusat Statistik Jawa Timur.

Badan Pusat Statistik. (2020). Berita Resmi Statistik, Keadaan Ketenagakerjaan Jawa Timur 2020. Surabaya: Badan Pusat Statistik Jawa Timur .

Badan Pusat Statistik. (2020). Tingkat Pengangguran Terbuka Provinsi Jawa Timur. Surabaya: BPS Provinsi Jawa Timur.

Badan Pusat Statistik. (2020). Upah Minimum Regional Kabupaten / Kota Jawa Timur. Provinsi Jawa Timur: Badan Pusat Statistik Provinsi Jawa Timur.

Badan Pusat Statistik. (2021). Indeks Pembangunan Manusia. Surabaya: Badan Pusat Statistik.

Badan Pusat Statistik. (2021). Jumlah Penduduk Hasil Proyeksi Menurut Provinsi dan Jenis Kelamin. Jakarta: Badan Pusat Statistik Indonesia.

Badan Pusat Statistik. (2021). Distribusi PDRB Terhadap Jumlah PDRB 34 Provinsi Atas Dasar Harga Berlaku Menurut Provinsi (Persen), 2018-2020. Jakarta: BPS.

BPS Jawa Timur. (2019). Laju Pertumbuhan Produk Domestik Regional Bruto Atas Harga Konstan.

BAPEMAS. (2013). Program Pemberdayaan Desa/kelurahan.

Cahyat, A. (November 2004). Bagaimana Kemiskinan di ukur? beberapa model perhitungan kemiskinan di Indonesia. Proverty \& Decentralization Project. CIFOR (Center for International Foresty Research, 2.

Chambers, R. (1983). Pembangunan Desa Mulai dari Belakang. Jakarta: LP3ES.

Fatimah, A. N. (2017). Analisis Faktor-Faktor Yang Mempengaruhi Tingkat Kemiskinan Kabupaten/Kota di Jawa Tengah Tahun 2012-2016. Jurnal Publikasi.

Gandasari, S. d. (2016). Pengaruh Indeks Pembangunan Manusia dan Pengangguran Terhadap Kemiskinan di Provinsi Banten. JEQu, 2.

Ghozali, I. (2006). Aplikasi Analisis Multivariate dengan Program SPSS. Semarang: Badan Penerbit Universitas Diponegoro.

Gujarati, D. (1995). Ekonometrika Dasar. Jakarta: Erlangga.

Hujaipah. (2020). Pengaruh Indeks Pembangunan Manusia (IPM) dan Upah Minimum Provinsi (UMP) terhadap tingkat Kemiskinan 11 Kabupaten/Kota di Provinsi Jambi (Tahun 20142019). Skripsi.

Kristanto, P. D. (2014). Analisis Pengaruh Pertumbuhan Ekonomi, Upah Minimum dan Tingkat Pengangguran Terhadap Jumlah Penduduk Miskin di Kabupaten Brebes Tahun 1997 2012. Economics. 


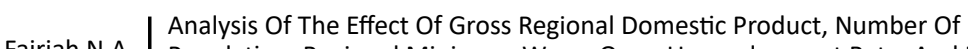

Fajriah N.A. Population, Regional Minimum Wage, Open Unemployment Rate, And Human Development Index On Poverty In 2010-2020 East Java Province

Kuncoro, M. (1997). Ekonomi Pembangunan Teori Masalah dan kebijakan. Jakarta: Unit Penerbit dan Percetakan PN.

Kuncoro, M. (2004). Ekonomi Pembangunan : Teori Masalah dan Kebijakan. Yogyakarta: UPP AMP YKPN.

Kuznets, S. (1955). Economic Growth and Income Inequality. In T. A. Review. American: American Economic Association.

Mahsunah, D. (2013). Analisis Pengaruh Jumlah Penduduk, Pendidikan dan Pengangguran Terhadap Kemiskinan di Jawa Timur . Jurnal Pendidikan Ekonomi (JUPE), 1(3).

Michael P Todaro dan Stephen C Smith. (2003). Pembangunan Ekonomi di Dunia Ke Tiga, Edisi Kedelapan. Jakarta: Erlangga.

Mulyaningsih, Y. (2008). Pengaruh Pengeluaran Pemerintah di Sektor Publik Terhadap Peningkatan Pembangunan Manusia dan Pengurangan Kemiskinan.

Nasir, D. (2008). Analisis Faktor-Faktor Yang Mempengaruhi Kemiskinan Rumah Tangga Di Kabupaten Purworejo. Jurnal Ekskutif, 5(4).

Prasetyo, P. (2009). Fundamental Makro Ekonomi. Yogyakarta: Beta Offset.

Pratiwi, U. A. (2018). Determinasi faktor yang mempengaruhi jumlah penduduk miskin provinsi di pulau sumatera pada tahun 2010-2016. skripsi.

Putri, S. d. (2019). Pengaruh Indeks Pembangunan Manusia, Pengangguran, dan Jumlah Penduduk Terhadap Tingkat Kemiskinan di Aceh Bagian Timur. Samudra Economika, 3.

Rachman H. (2005) dalam Prabowo Dwi Kristanto (2014). (n.d.). Analisis Pengaruh Pertumbuhan Ekonomi, Upah Minimum dan Tingkat Pengangguran Terhadap Tingkat Kemiskinan di Kabupaten Brebes Tahun 1997-2012.

Ricardo, D. (1917). The Principles of Political Economy and Taxation.

Saputra, W. A. (2011). Analisis Pengaruh Jumlah Penduduk, PDRB, IPM Pengangguran Terhadap Tingkat Kemiskinan di Kabupaten / Kota Jawa Tengah. Journal Undip.

Sharp R.Y. (2000). Steps in Commulative Algebra. Cambridge University Press.

Siregar, H \& Wahyuniarti, D. (2008). Dampak Pertumbuhan Ekonomi Terhadap Penurunan Jumlah Penduduk Miskin.

Skousen, M. (2009). Sejarah Pemikiran Ekonomi Sang Maestro. Jakarta: Prenada.

Smith, M. P. (2006). Pembangunan Ekonomi, Edisi 9. Jakarta: Erlangga.

Soegijoko. (1997). Bunga Rampai Perencanaan Pembangunan di Indonesia. bandung: Yayasan Soegijanto Soegijoko.

Srilastri, N. (2017). Pengaruh Jumlah Penduduk dan PDRB terhadap kemiskinan di Kabupaten Kuantan Singingi. JOM Fecom, 1.

Suparmoko M. (2002). Ekonomi Publik untuk Keuangan dan Pembangunan Daerah, edisi 1. Yogyakarta: Andi Yogyakarta.

Sukirno, S. (1994). Pengantar Ekonomi Makro Edisi Kedua. Jakarta: PT Rajagrafindo Perkasa. 
Sukirno, S. (1999). Teori Pengantar Makroekonomi. Jakarta: Grafindo Persada.

Suradi. (2011). Pengaruh Dektor Informal dalam Pennggulangan Kemiskinan. informasi.

Survey Angkatan Kerja Nasional (SANKERNAS). (2019). Publikasi Kependudukan. Provinsi Jawa Timur: Badan Pusat Statistik.

Todaro, M. (1995). Pembangunan Ekonomi di Dunia Ketiga Edisi 4. Jakarta: Erlangga.

UNDP. (1990). Indeks Pembangunan Manusia.

UNDP. (1995). Indeks Pembangunan Manusia.

Widarukmi, L. P. (2015). analisis faktor-faktor yang mempengaruhi kemiskinan di kota surakarta tahun 1995-2013. naskah ilmiah .

widyawati, w. n. (2017). Analisis pengaruh Pendidikan, Upah Minimum Kabupaten/kota dan PDRB terhadap jumlah penduduk miskin se-karesidenan Madiun tahun 2004-2014 . skripsi.

widyawati, w. n. (2017). analisis pengaruh pendidikan, upah minimum kabupaten/kota, dan pdrb terhadap jumlah penduduk miskin se-karasidenan madiun tahun 2004-2014. Economics.

wongdesmiwati. (2009). Pertumbuhan Ekonomi dan Pengentasan Kemiskinan di Indoensia. Analisis Ekonometrika.

World Bank. (2004). Definisi Kemiskinan.

Yacoub, Y. (2012). Pengaruh Tingkat Pengangguran terhadap Tingkat Kemiskinan Kabupaten/ Kota di Provinsi Kalimantan Barat. Economics, 176-185.

Yudha, O. R. (2013). Pengaruh Pertumbuhan Ekonomi, Upah Minimum, Tingkat Pengangguran Terbuka Dan Inflasi Di Indonesia Tahun 2009 2011. Journal Unnes. 